\title{
PENERAPAN MODEL MERSIS PRO PADA PEMBELAJARAN SISTEM KOLOID UNTUK MENINGKATKAN KEMAMPUAN METAKOGNITIF DAN HASIL BELAJAR SISWA
}

\section{THE APPLICATION OF MERSIS PRO MODEL ON COLLOID SYSTEM TO IMPROVE STUDENTS' METACOGNITIVE ABILITY AND LEARNING OUTCOMES}

\author{
Idha Nurhayati \\ Sekolah Menengah Atas Negeri 1 Pati \\ Email : aktinidha@yahoo.com
}

Naskah Masuk: 5 Maret 2018

Naskah Revisi: 13 April 2018

Naskah Diterima: 16 April 2018

\begin{abstract}
The students of 11th grade Science 6 SMAN 1 Pati, school year 2016/2017 performed low metacognitive ability and learning outcome on colloid system material. This research aimed to describe the increase of metacognitive ability and learning outcomes through Mersis Pro models on Colloid System material. A total of 32 students eleventh grade were involved in a class action research, which consisted of 2 cycles. Furthermore, every cycle was divided into four stages: planning, implementation, observation, and reflection. The data were collected through documentation, observation and questionnaire. Data analysis used both qualitative and quantitative descriptive methods. The results showed that: (1) learning process increased by $15.97 \%$, (2) learning activity increased by $15.60 \%$, (3) metacognitive ability increased by $12.51 \%$, (4) learning outcomes increased by $14.68 \%$. Mersis Pro model was proved as an active, creative, effective, challenging and fun learning method
\end{abstract}

Keywords: learning outcomes, metacocnitive ability Mersis Pro models, colloid system

\begin{abstract}
ABSTRAK
Hasil belajar siswa kelas XI 6 SMAN 1 Pati tahun pelajaran 2016/2017 pada materi Sistem Koloid menunjukkan hasil belajar dan kemampuan metacognitif yang cenderung rendah. Tujuan penelitian adalah menggambarkan peningkatan kemampuan metakognitif dan hasil belajar siswa melalui model Mersis Pro pada pembelajaran Sistem Koloid. Subjek dalam penelitian ini adalah 32 siswa kelas XI IPA 6 SMAN 1 Pati tahun pelajaran 2016/2017. Penelitian tindakan kelas dilaksanakan dalam 2 siklus. Setiap siklus terdiri dari empat tahap: perencanaan, pelaksanaan, observasi, dan refleksi. Data penelitian diperoleh dari dokumentasi, observasi dan kuesioner. Analis data menggunakan metode deskriptif, baik kualitatif maupun kuantitatif. Hasil penelitian menunjukkan bahwa: (1) proses belajar meningkat sebesar 15,97\%, (2) aktivitas belajar meningkat sebesar 15,60\%, (3) kemampuan metakognitif meningkat sebesar 12,51\%, (4) hasil belajar meningkat sebesar 14,68. Model Mersis Pro terbukti sebagai metode pembelajaran yang aktif, kreatif, efektif, menantang dan menyenangkan.
\end{abstract}

Kata kunci : hasil belajar, kemampuan metakognitif, model mersis pro, sistem koloid 


\section{PENDAHULUAN}

Pemahaman konsep Sistem Koloid dalam pembelajaran kimia dapat dimanfaatkan siswa dalam kehidupan sehari-hari. Hal tersebut diantaranya berupa penerapan konsep elektroforesis dalam alat corttrell untuk mencegah polusi udara, adsorbsi sebagai teknik pewarnaan pada tekstil, koagulasi dalam penjerrnihan air kotor dan lain-lain.

Namun demikian, banyak siswa yang tidak menyukai pembelajaran tersebut. Wawancara dengan beberapa siswa, menunjukkan bahwa kurangnya minat siswa disebabkan oleh isi dari materi sistem koloid yang bersifat konsep teoritis. Sementara itu guru mengajarkanya secara monoton dengan metode ceramah-diskusi, sehingga siswa tidak tertarik, bosan dan cenderung meremehkanya, akibatnya hasil belajar siswa menjadi rendah. Hal tersebut tampak dari nilai ulangan Sistem Koloid yang diperoleh siswa dalam tiga tahun terakhir: nilai rata-rata siswa hanya sebesar 70,24, masih jauh lebih rendah dibandingkan dengan KKM yaitu 78 . Demikian juga dengan persentase ketuntasan klasikal yang masih rendah yaitu $68,72 \%$.

Pembelajaran Sistem koloid tidak sesederhana yang siswa pikirkan. Untuk dapat memahami dan menerapkan konsep koloid dalam kehidupan secara benar, dibutuhkan pemahaman yang mendalam tentang konsep tersebut. Siswa dituntut aktif menggali pengetahuan melalui proses berfikirnya sendiri. Selain itu, siswa diharapkan mempunyai kesadaran berfikir tentang apa yang harus dilakukanya, yang kemudian disebut dengan metakognitif. Menurut (Nuryana \& Sugiarto, 2012), metakognitif merupakan faktor yang penting dalam proses pembelajaran karena metakognitif mempunyai hubungan langsung yang positif dengan pencapaian akademik, artinya semakin tinggi kesadaran metakognitif maka semakin baik pula hasil belajar siswa Filsafat Konstruktivisme menyatakan bahwa belajar bukanlah sekedar menghapal tetapi proses mengkonstruksi pengetahuan melalui pengalaman (Suparno, 2008). Proses konstruksi pengetahuan oleh siswa akan lebih optimal apabila dilakukan melalui metode penemuan. Hal tersebut dikarenakan pengetahuan hasil temuan akan bertahan lama dan memberikan hasil yang lebih baik. Menurut Andayani (2012), pembelajaran akan lebih produktif dan bermakna apabila siswa mengalami bukan menghafal apa yang dipelajarinya dalam kehidupan mereka (Contextual). Sedangkan menurut Dryden (2009), belajar akan efektif jika dilakukan dalam suasana yang nyaman dan menyenangkan.

Berdasarkan beberapa pendapat tersebut, peneliti mencoba menggagas suatu inovasi dalam pembelajaran Sistem Koloid dengan merancang model pembelajaran Mersis Pro (Pameran Berbasis Proyek). Model pembelajaran Mersis Pro mengkondisikan siswa agar aktif terlibat secara langsung dalam pembelajaran yang berhubungan dengan lingkungan yang nyata. Siswa mencari informasi, melakukan pengamatan dan, menganalisa data untuk menemukan konsep-konsep dalam sistem Koloid, kemudian mewujudkan konsep-konsep tersebut dalam sebuah proyek serta menyajikan hasil proyek tersebut dalam sebuah pameran untuk mendapatkan apresiasi dari setiap pengunjung. Melalui tahapan tersebut pembelajaran ini menjadi menarik dan menyenangkan.

Dibandingkan dengan model pembelajaran yang lainya, model Mersis Pro memilki keunggulan yaitu mampu memadukan 4 (empat) model pembelajaran sekaligus; Contextual, Discovery, PBJL dan Gallery. Sehingga 
model pembelajaran ini menjadi pilihan yang tepat untuk mengembangkan kemampuan metakognitif, kreatifitas dan aktivitas siswa dalam pembelajaran sistem Koloid.

Tujuan dari penelitian ini adalah: 1) Mendeskripsikan keterlaksanaan proses pembelajaran Sistem Koloid dengan menerapkan model Mersis Pro untuk meningkatkan kemampuan metakognitif dan hasil belajar siswa kelas XI IPA 6 SMA N 1 Pati Tahun Pelajaran 2016/2017. 2) Mengetahui seberapa banyak peningkatan kemampuan metakognitif dan hasil belajar siswa kelas XI IPA 6 SMA N 1 Pati Tahun Pelajaran 2016/2017 setelah penerapan model Mersis Pro pada pembelajaran Koloid.

\section{TINJAUAN PUSTAKA}

\section{Kemampuan Metakognitif}

Metakognitif adalah kesadaran seseorang bagaimana ia belajar, suatu kemampuan untuk menillai kesukaran masalah, kemampuan untuk mengamati tingkat pemahaman dirinya, kemampuan untuk menggunakan berbagai informasi untuk mencapai tujuan, kemampuan menilai kemampuan belajar sendiri. (Husamah dan Setyaningrum, 2013).

Menurut Schraw \& Dennison, (1994), kemampuan metakognitif mencakup dua aspek yaitu: (1) pengetahuan metakognitif (metacognitive knowledge) yang meliputi; declarative knowledge, procedural knowledge, dan conditional knowledge; (2) regulasi metakognitif (metacognitive regulation) meliputi: planning, information management strategies, comprehension monitoring, debugging, strategies dan evaluation. Jadi kemampuan metakognitif merupakan kemampuan siswa melakukan self reflection, self monitoring atau self awareness dari kegiatan belajar yang telah dilakukannya.

Dalam penelitian ini aspek-aspek tersebut diwujudkan dalam perilaku sebagai berikut: (1) mengidentifikasi masalah, (2) merencanakan apa yang akan dilakukan, (3) menyiapkan alatbahan apa yang dipakai, (4) memilih solusi yang tepat, (5) mengurutkan tahaptahap yang digunakan dalam penyelesaian masalah, (6) memonitor setiap langkah yang dilakukan, (7) mengecek jawaban hasil penyelidikan, (8) mempertimbangkan ketepatan hasil penyelidikan, (9) memperbaiki kesalahan kesalahan, (10) menilai hasil penyelidikan, (11) menilai pencapaian tujuan, (12) membuat kesimpulan.

Coutinho (2007) menyatakan bahwa ada hubungan positif antara prestasi belajar dengan matakognitif. Siswa yang memiliki keterampilan metakognitif yang baik akan pula menunjukkan prestasi belajar yang baik.

\section{Hasil Belajar}

Belajar merupakan suatu proses dari seseorang yang berusaha untuk memperoleh suatu bentuk perubahan perilaku yang baru secara keseluruhan, sebagai hasil pengalamannya sendiri dalam interaksi dengan lingkungannya (Slameto, 2003).

Menurut Sudjana (2005), hasil belajar adalah kemampuan-kemampuan yang dimiliki peserta didik setelah ia menerima pengalaman belajarnya. Hasil belajar pada hakekatnya adalah perubahan tingkah laku pada peserta didik. Tingkah laku sebagai hasil belajar dalam pengertian yang luas mencakup bidang kognitif, afektif, dan psikomotorik.

\section{Pembelajaran Berbasis Proyek (PJBL)}

Menurut Trianto (2010), Project Based Learning adalah sebuah model atau pendekatan pembelajaran yang inovatif, yang menekankan belajar kontekstual melalui kegiatan-kegiatan yang kompleks yaitu merancang kegiatan, mempraktekan, memecahkan masalah, membuat keputusan, melakukan 
kegiatan serta evaluasi tindak lanjut dan pada akhirnya akan menghasilkan suatu produk nyata. Mengacu pada pendapat tersebut dapat dinyatakan bahwa model pembelajaran berbasis proyek merupakan model pembelajaran inovatif yang mengadopsi teori konstruktivisme dan pembelajaran kontektual.

Wena (2014) menyatakan, strategi pembelajaran berbasis proyek terdiri dari tiga tahap utama, yaitu: 1) Tahap perencanaan pembelajaran proyek, 2) Tahap pelaksanaan pembelajaran proyek, dan 3) Tahap evaluasi pembelajaran proyek.

\section{Penerapan Model Mersis Pro pada Pembelajaran Sistem Koloid}

Model pembelajaran Mersis Pro (Pameran berbasis Proyek) merupakan model pembelajaran yang inovatif, menarik, menantang dan menyenangkan. Dengan segala kelebihanya, model pembelajaran Mersis Pro diharapkan mampu mengatasi permasalahan dalam pembelajaran Koloid yang selama ini masih menggunakan metode ceramah dan diskusi.

Model pembelajaran Mersis Pro mengadopsi beberapa teori belajar diantaranya adalah teori konstruktivistik yang menyatakan pengetahuan itu akan bermakna manakala dicari dan ditemukan sendiri oleh siswa. Teori Kontekstual menyatakan; pembelajaran kontekstual membantu guru mengaitkan materi yang diajarkan dengan situasi dunia nyata sehingga siswa memperoleh pengalaman bermakna (Rusman, 2010). Sedangkan menurut (Kramarski dan Mevarech, 2003), kemampuan metakognitif dapat dikembangkan dengan melalui pelatihan metakognitif berdasar pendekatan Polya dalam memecahkan masalah.

Pembelajaran Mersis Pro dilaksanakan di laboratorium kimia dengan fasilitas bahan-alat praktikum, multimedia, buku dan LKS yang telah dipersiapkan oleh guru. Dengan bimbingan guru, siswa diberikan keleluasaan untuk membangun pengetahuanya dan menemukan konsepkonsep koloid sendiri, melalui kegiatan mengamati, mencoba, mempraktekkan, mengumpulkan data, menganalisa datadata dan mengkomunikasikan hasil temuan diskusi untuk mendapatkan suatu kesimpulan umum. Setelah siswa dapat menemukan dan memahami konsepkonsep tentang Koloid, selanjutnya siswa merencanakan sebuah proyek tentang koloid dengan tema sesuai pilihan mereka. Proyek diselesaikan secara berkelompok di luar jam pembelajaran. Hasil dari proyek yang telah dikerjakan siswa, kemudian disajikan dalam sebuah pameran kelas.

Pameran merupakan kegiatan untuk memperkenalkan produk, karya atau ide kepada masyarakat luas. Pameran yang dimaksud dalam penelitian ini adalah pameran kelas yang menyajikan hasil proyek siswa terkait dengan konsep-konsep koloid yang telah dipelajarinya, sebagai contoh adalah prototype dari sistem dialisis pada ginjal, alat penjernih air, bentuk-bentuk koloid pada makanan dan lain-lain. Pameran ini digelar untuk mengkomunikasikan hasil proyek kepada pengunjung, yang dalam hal ini adalah rekan-rekan dan gururnya.

Dalam pameran kelas, sejumlah siswa dalam kelompok dibagi menjadi penjaga stand dan pengunjung stand. Penjaga stand mempunyai kewajiban menjawab pertanyaan dan menerima masukan pengunjung. Sedangkan pengunjung stand mempunyai tugas mengumpulkan informasi dari standstand lainya. Akhirnya semua anggota suatu kelompok berkumpul, siswa-siswa pengunjung stand mempunyai kewajiban menularkan informasinya kepada siswa penjaga stand dan sebaliknya. 
Tampak dari tahapan-tahapanya, pembelajaran Mersis Pro memberikan keleluasaan penuh kepada siswa untuk merencanakan belajarnya, mengatur proses berfikirnya, memantau proses belajarnya sendiri dan mengevaluasi hasil belajar. Tahapan tersebut sejalan dengan strategi metakognitif. Dengan demikian, besar harapan model pembelajaran Mersis Pro akan dapat meningkatkan kemampuan metakognitif dan hasil belajar siswa pada pembelajaran Sistem Koloid.

\section{METODE PENELITIAN}

Penelitian ini dilaksanakan pada semester genap (kedua) tahun pelajaran 2016/2017 pada bulan april sampai dengan bulan Mei 2017 di SMA Negeri 1 Pati dengan subjek penelitian siswa kelas XI IPA 6 SMA Negeri 1 Pati yang terdiri dari 32 siswa (22 siswa perempuan dan 10 siswa laki-laki).

Prosedur penelitian tindakan kelas pada penelitian ini terdiri dari dua siklus. Hal ini telah memenuhi persyaratan sesuai dengan pendapat (Suyitno, 2005) yang menyatakan bahwa dalam suatu penelitian tindakan kelas perlu ada siklus kegiatan sekurang-kurangnya dua siklus, dimana pada setiap siklus kegiatan pembelajaran dimulai dari perencanaan, pelaksanaan tindakan, observasi, dan refleksi.

\section{Pelaksanaan Siklus 1}

Rincian pelaksanaan penelitian tindakan kelas pada siklus 1 adalah sebagai berikut, Perencanaan: Kegiatan yang dilakukan peneliti pada tahap perencanaan ini adalah: 1) Dokumentasi kondisi awal siswa 2) Mengobservasi kemampuan metakognitif siswa. 3) Perencanaan tindakan kolaborasi antara Guru dan guru mitra (observer). 4) Guru menyusun jadwal kegiatan penelitian. 5) Guru menyusun rencana pelaksanaan pembelajaran, lembar kegiatan siswa, lembar observasi kegiatan metakognitif, lembar observasi kegiatan guru, angket kemampuan metakognitif dan alat evaluasi akhir siklus. (6) Guru membuat keompok-kelompok siswa.

Pelaksanaan tindakan kegiatan yang dilakukan guru pada tahap pelaksanaan ini adalah: 1) Guru membuka pembelajaran dengan ucapan salam, kemudian memberikan motivasi dan apersepsi tentang pentingnya materi Sistem Koloid, serta menjelaskan keterkaitan materi Sistem Koloid dengan kehidupan sehari-hari mereka dan tujuan pembelajaran; 2) Guru menjelaskan alur langkah-langkah pembelajaran secara menyeluruh yang akan dilaksanakan; 3) Guru membagi siswa dalam beberapa kelompok belajar; 4) Guru memberikan stimulan dan memberikan gambaran secara garis besar mengenai materi pembelajaran koloid yang akan dipelajari oleh siswa; 5) Guru memberikan tugas pembelajaran yaitu menemukan konsepkonsep koloid dari berbagai sumber liiteratur atau dengan memanfaatkan alat dan bahan yang ada di laboratorium dan menjawab pertanyaan yang ada di LKS; 6) Guru memandu., membimbing dan menjawab pertanyaan siswa dalam diskusi kelompok dan mempersilahkan siswa memanfaatkan alat dan bahan yang tersedia di laboratorium untuk membantu memahami materi pembelajaran koloid yang dipelajarinya; 7) Guru meminta siswa untuk menuliskan pertanyaanpertanyaan yang tidak dapat diselesaikan sebagai bahan untuk diskusi kelas; 8) Siswa menyerahkan hasil jawaban dari pertanyaan yang ada pada LKS; 9) Siswa mengadakan diskusi kelas dengan arahan guru. Setiap kelompok mengemukakan pertanyaan dan kelompok lain diberikan kesempatan untuk menanggapi atau menjawabnya; 10) Guru bersama-sama dengan siswa membuat kesimpulan mengenai materi koloid yang dipelajari berdasarkan temuan siswa; 11) Siswa 
merencanakan sebuah proyek terkait temuan konsep-konsep koloid mereka. Adapun tema dari proyek sepenuhnya ditentukan oleh kesepakatan siswa. Proyek dilaksanakan dengan tahapan sebagai berikut: (a) Penentuan proyek; (b) Perancangan langkah-langkah penyelesaian proyek; (c) Penyusunan jadwal dan tempat pelaksanaan proyek; (d) Penyelesaian proyek dengan fasilitasi dan monitoring guru; (e) Penyusunan laporan proyek; (f) Evaluasi proses dan hasil proyek; 12) Siswa merencanakan pameran hasil proyek dengan ketentuan sebagai berikut: (a) setiap kelompok yang terdiri dari 4 siswa, dengan tugas; 2 orang menjaga stand pameran bertugas menjawab semua pertanyaan pengunjung dan 2 orang lainya mengunjungi stand pameran lainya dan bertugas mencari informasi koloid dari stand lainya; 13) Siswa menggelar pameran; 14) Penjaga stand menjawab setiap pertanyaan dan menerima masukan dari pengunjung; 15) Guru menilai hasil proyek yang disajikan dalam pameran; 16) Semua anggota kelompok akhirnya bertemu. Pengunjung stand mempunyai kewajiban menularkan informasinya kepada anggota kelompok yang lain dan sebaliknya; 17) Setelah berdiskusi, setiap kelompok tampil mempresentasikan inovasi koloidnya; 18) Guru dan siswa bersama-sama membuat kesimpulan secara menyeluruh tentang koloid; 19) Pada akhir pembelajaran guru mereview hasil kerja siswa dan melakukan refleksi dengan tanya jawab mengenai pembelajaran yang telah dilaksanakan. Pada akhir siklus 1 siswa melaksaanakan tes hasil belajar dan dilanjutkan dengan mengisi angket kemampuan metakognitif siklus 1.

Observasi digunakan untuk mengukur keterlaksanaan pembelajaran, kegiatan metakognitif siswa dan pameran proyek. Dalam observasi ini digunakan instrumen pedoman observasi. Observasi terhadap siswa dilakukan secara kolaboratif antara peneliti (guru) dengan observer sedangkan untuk observasi aktifitas guru dilakukan oleh observer. Penilaian hasil belajar siswa diperoleh dari tes pada akhir siklus 1, penilaian kemampuan metakognitif diperoleh dari data angket yang diisi siswa dan penilaian aktifitas siswa dan kegiatan guru diperoleh dari lembar observasi.

Pengukuran (kuesioner) kesadaran metakognitif yang digunakan pada penelitian ini mengacu kepada kesadaran metakognitif menurut Schraw dan Dennison, dengan menggunakan kuesioner atau inventori yang telah terstandar, disusun oleh Sperling dkk seperti yang disarankan oleh Panaoura dan Philippou dalam Paidi, (2005) yaitu metakognitive Awareness Inventory Junior (MAI-Jr) yang telah banyak dipakai oleh para peneliti metakognitif pada anak-anak/ remaja (young pupil). MAI-Jr terdiri dari aspek pengetahuan metakognitif (metacognitive knowledge) dengan subaspek: declarative knowledge, procedu ral knowledge, dan conditi onal knowledge serta aspek regulasi metakognitif (metacognitive regulation) yang terdiri dari sub aspek: planning, information, management strategies, comprehension monitoring, debugging strategies dan evaluation.

Data yang diperoleh pada siklus 1 dikumpulkan untuk kemudian dianalisis, berdasarkan hasil analisis tersebut, dilakukan refleksi sehingga dapat diketahui apakah terjadi peningkatan kemampuan metakognitif dan hasil belajar setelah adanya tindakan.

\section{Pelaksanaan Siklus 2}

Secara umum tahapan pelaksanaan tindakan siklus 2 sama dengan siklus 1, disertai beberapa perbaikan berdasarkan hasil refleksi tindakan pada siklus 1 .

\section{Teknik Pengumpulan data}

Sumber data dalam penelitian ini adalah siswa kelas XI IPA 6 SMA N 1 
Pati, guru mitra sebagai observer serta dokumen pembelajaran. Jenis data yang diperoleh dalam penelitian ini ada dua, yaitu data kuantitatif dan data kualitatif. Dimana data kuantitatif berupa data hasil belajar siswa, dan data angket dan dokumen/referensi, sedangkan data kualitatif adalah data hasil observasi.

\section{Teknik Analisis Data}

Cara pengambilan data dalam penelitian ini antara lain, sebagai berikut: (1) metode tes digunakan untuk mengumpulkan data hasil belajar siswa. (2) metode dokumentasi digunakan untuk pengumpulan data yang berupa silabus, RPP, nilai siswa dan data siswa. (3) metode Angket digunakan untuk memperoleh data mengenai kemampuan metakognitif siswa. (4) metode Observasi digunakan untuk mengukur keaktifan siswa, kegiatan guru dan faktor-faktor yang dapat dijadikan bahan pertimbangan dalam tindakan berikutnya.

Data hasil angket dan observasi divalidasi dengan triangulasi sumber secara kolaboratif dengan guru BP dan guru mitra, sedangkan validasi terhadap instrumen penilaian tes akhir siklus berupa penyusunan kisi-kisi, sehingga terpenuhi validitas teoretik, khususnya content validity.

Data penelitian yang terkumpul dianalisis secara deskriptis kuantitatif dan kualitatif yaitu dengan membandingkan data kemampuan metakognitif dan hasil belajar siswa sebelum \&setelah tindakan.

\section{Indikator Keberhasilan}

Indikator keberhasilan dalam penelitian ini ditetapkan sebagai berikut, Penelitian ini dinyatakan berhasil jika: (1) Tingkat keterlaksanaan proses pembelajaran Model Mersis Pro, sekurang-kurangnya mencapai $85 \%$. (2) Sekurang-kurangnya $85 \%$ secara klasikal siswa aktif melaksanakan kegiatan metakognitif dalam pembelajaran. (3)
Sekurang-kurangnya $85 \%$ secara klasikal siswa memiliki kemampuan metakognitif yang baik dalam pembelajaran. (4) Sekurang-kurangnya $85 \%$ siswa telah tuntas belajar secara klasikal (mendapat nilai di atas KKM : 78).

\section{HASIL DAN PEMBAHASAN}

\section{Deskripsi Kondisi Awal}

Berdasarkan pengamatan sebelum penelitian, pembelajaran kimia yang berlangsung selama ini bersifat satu arah di mana guru berperan sebagai sumber pengetahuan, sehinga siswa menjadi pasif, malas berfikir dan sepenuhnya hanya bergantung pada guru. Sistem pembelajaran yang demikian menjadikan hasil belajar siswa belum optimal.

Untuk mengatasi hal tersebut guru harus memilih model pembelajaran yang tepat. Model Mersis Pro mampu meningkatkan kemampuan metakognitif dan hasil belajar siswa pada materi Sistem Koloid. Berikut ini adalah data sebelum penelitian yang diperoleh dari nilai ulangan akhir semester 1 siswa kelas XI IPA 6.

Tabel 1. Nilai Ulangan Akhir Semester 1 Siswa Kelas XI IPA 6

\begin{tabular}{clc}
\hline No. & \multicolumn{1}{c}{ Hasil Tes } & Pencapaian \\
\hline 1 & Nilai tertinggi & 80 \\
2 & Nilai terendah & 34 \\
3 & Nilai rata-rata & 62,14 \\
4 & Jumlah siswa tuntas & 20 \\
5 & $\%$ ketuntasan & $62,50 \%$ \\
\hline
\end{tabular}

Sumber: Pengolahan Data (2017)

Berdasarkan Tabel 1, masih banyak siswa yang belum tuntas belajar dan persentase ketuntasan belajar secara klasikal masih rendah yaitu 62,50\%.

\section{Hasil Siklus 1}

Kondisi proses pembelajaran, hasil belajar, keaktifan dan kemampuan 
metakognitif siswa setelah diberi tindakan siklus 1 disajikan pada Tabel 2.

Tabel 2.

Hasil Pengamatan Keterlaksanaan Proses Pembelajaran Siklus 1

\begin{tabular}{lccc}
\hline \multicolumn{1}{c}{ Kategori } & Interval & Skor & $\%$ \\
\hline Sangat baik & $105-128$ & - & - \\
Baik & $81-104$ & 94 & 73,44 \\
Tidak baik & $57-80$ & - & - \\
Sangat tidak Baik & $32-56$ & - & - \\
\hline
\end{tabular}

Sumber: Pengolahan Data (2017)

Tabel 2 menunjukkan bahwa dari seluruh aspek proses pelaksanaan pembelajaran yang diamati, diperoleh skor 94 (73,44\% dari yang direncanakan) $\&$ termasuk dalam kategori baik.

Tabel 3.

Hasil Pengamatan Keaktifan Siswa Siklus 1

\begin{tabular}{|c|c|c|c|c|}
\hline \multirow{2}{*}{ Kategori } & \multirow{2}{*}{ Interval } & \multicolumn{2}{|c|}{ Pertemuan } & \multirow{2}{*}{$\begin{array}{c}\% \\
\text { rata-rata }\end{array}$} \\
\hline & & 1 & 2 & \\
\hline Sangat aktif & $40-48$ & 3 & 5 & 12,50 \\
\hline Aktif & $31-39$ & 21 & 20 & 64,06 \\
\hline Tidak aktif & $22-30$ & 8 & 7 & 23,44 \\
\hline $\begin{array}{l}\text { Sangat tidak } \\
\text { aktif }\end{array}$ & $12-21$ & - & - & - \\
\hline
\end{tabular}

Sumber: Pengolahan Data (2017)

Tabel 3 menjelaskan rata-rata keaktifan siswa pada siklus 1 berdasarkan pertemuan ke-1 dan ke-2. Siswa yang sangat aktif pada siklus 1 rata-rata $12,5 \%$ siswa. Adapun siswa yang aktif pada siklus 1 rata-rata 64,06\%. Sedangkan siswa lainya cenderung tidak aktif.

Tabel 4.

Hasil Angket Kemampuan Metakognitif Siswa Siklus 1

\begin{tabular}{lccr}
\hline \multicolumn{1}{c}{ Kategori } & Interval & Jmlh & $\%$ \\
& \multicolumn{3}{c}{ Siswa } \\
\hline Sangat baik & $114-140$ & 1 & 3,12 \\
Baik & $87-113$ & 24 & 75,00 \\
Tidak baik & $60-86$ & 7 & 21,88 \\
Sangat tidak baik & $32-59$ & - & - \\
\hline Sumber: Pengolahan Data (2017)
\end{tabular}

Tabel 4 menjelaskan bahwa persentase siswa yang mempunyai kemampuan metakognitif sangat baik sebesar 3,12\% dan kemampuan metakognitif kategori baik sebesar $75,00 \%$. Tabel 4 juga menunjukkan masih adanya siswa yang memiliki kemampuan metakognitif dalam kategori tidak baik.

\section{Tabel 5.}

Hasil Belajar Pengetahuan Siswa pada Tes Akhir Siklus 1

\begin{tabular}{llr}
\hline No. & \multicolumn{1}{c}{ Hasil Tes } & Pencapaian \\
\hline 1 & Nilai tertinggi & 86,67 \\
2 & Nilai terendah & 40 \\
3 & Nilai rata-rata & 75,21 \\
4 & Jumlah siswa tuntas & 23 \\
5 & \% ketuntasan & $71,88 \%$ \\
\hline
\end{tabular}

Sumber: Pengolahan Data (2017)

Data pada Tabel 5 menunjukkan bahwa nilai rata-rata siswa sebesar 75,21, sedangkan persentase ketuntasan hanya mencapai 71,88 \%. Dengan demikian hasil belajar pada tes akhir siklus 1 masih belum memenuhi target yang diharapkan.

\section{Hasil Siklus 2}

Berikut adalah hasil data setelah pelaksanaan tindakan pada siklus 2 .

Tabel 6.

Hasil Pengamatan Keterlaksanaan Proses Pembelajaran Siklus 2

\begin{tabular}{lccc}
\hline \multicolumn{1}{c}{ Kategori } & Interval & Skor & $\%$ \\
\hline Sangat baik & $105-128$ & 114 & 89,06 \\
Baik & $81-104$ & - & - \\
Tidak baik & $57-80$ & - & - \\
Sangat tidak Baik & $32-56$ & - & - \\
\hline
\end{tabular}

Sumber: Pengolahan Data (2017)

Berdasarkan Tabel 6 diketahui bahwa dari seluruh aspek proses pelaksanaan pembelajaran yang diamati, diperoleh skor 114 atau 89,06\% dari yang direncanakan dan termasuk dalam kategori sangat baik. 
Tabel 7 menjelaskan rata-rata keaktifan siswa pada siklus 2 berdasarkan pertemuan kesatu dan kedua. Siswa yang sangat aktif pada siklus 2 rata-rata $29,69 \%$ siswa. Adapun siswa yang aktif pada siklus 2 rata-rata $62,5 \%$. Keaktifan siswa pada siklus 2 sudah memenuhi target.

Tabel 7.

Hasil Pengamatan Keaktifan Siklus 2

\begin{tabular}{|c|c|c|c|c|}
\hline \multirow{2}{*}{ Kategori } & \multirow{2}{*}{ Interval } & \multicolumn{2}{|c|}{ Pertemuan } & \multirow{2}{*}{$\begin{array}{r}\% \\
\text { rata- } \\
\text { rata }\end{array}$} \\
\hline & & 1 & 2 & \\
\hline Sangat aktif & $40-48$ & 7 & 12 & 29,69 \\
\hline Aktif & $31-39$ & 22 & 18 & 62,5 \\
\hline Tidak aktif & $22-30$ & 3 & 2 & 7,83 \\
\hline $\begin{array}{l}\text { Sangat tidak } \\
\text { aktif }\end{array}$ & $12-21$ & - & - & - \\
\hline
\end{tabular}

Tabel 8.

Peningkatan Keaktifan siswa Per-aspek yang Diamati dari Siklus 1 ke siklus 2

\begin{tabular}{|c|c|c|c|}
\hline \multirow{2}{*}{$\begin{array}{c}\text { Aspek } \\
\text { no. }\end{array}$} & \multicolumn{2}{|c|}{ Prosentase Keaktifan } & \multirow{2}{*}{$\begin{array}{l}\text { Prosentase } \\
\text { Peningkatan }\end{array}$} \\
\hline & Siklus1 & Siklus 2 & \\
\hline 1 & 72,26 & 78,52 & 6,26 \\
\hline 2 & 71,48 & 78,13 & 6.65 \\
\hline 3 & 71,44 & 76,56 & 5,12 \\
\hline 4 & 66,02 & 75,00 & 8,80 \\
\hline 5 & 73,05 & 76,17 & 3,12 \\
\hline 6 & 68,70 & 73,44 & 4,74 \\
\hline 7 & 70,31 & 75,78 & 5,74 \\
\hline 8 & 67,58 & 70,31 & 2,73 \\
\hline 9 & 69,14 & 74,61 & 5,47 \\
\hline 10 & 68,31 & 71,88 & 3,57 \\
\hline 11 & 71,05 & 74,61 & 3,56 \\
\hline 12 & 73,83 & 78,52 & 4,69 \\
\hline rerata & 70,26 & 75,29 & 5,04 \\
\hline
\end{tabular}

Sumber: Pengolahan Data (2017)
Tabel 9.

Hasil Angket Kemampuan Metakognitif Siswa Siklus 2

\begin{tabular}{lccc}
\hline \multicolumn{1}{c}{ Kategori } & Interval & $\begin{array}{c}\text { Jumlah } \\
\text { Siswa }\end{array}$ & $\%$ \\
\hline Sangat baik & $114-140$ & 3 & 9.375 \\
Baik & $87-113$ & 26 & 81,25 \\
Tidak baik & $60-86$ & 3 & 9,375 \\
$\begin{array}{l}\text { Sangat tidak } \\
\text { baik }\end{array}$ & $32-59$ & - & - \\
\hline
\end{tabular}

Sumber: Pengolahan Data (2017)

Berdasarkan Tabel 9 diketahui bahwa kemampuan metakognitif siswa kategori sangat baik mencapai 9,375\% dan kategori baik mencapai $81,25 \%$. Hasil ini telah memenuhi target penelitian.

Tabel 10.

Hasil Belajar Pengetahuan Siswa pada Tes Akhir Siklus 1

\begin{tabular}{clc}
\hline No. & \multicolumn{1}{c}{ Hasil Tes } & Pencapaian \\
\hline 1 & Nilai tertinggi & 100 \\
2 & Nilai terendah & 70 \\
3 & Nilai rata-rata & 86,15 \\
4 & Jumlah siswa tuntas & 28 \\
5 & $\%$ ketuntasan & $87,50 \%$ \\
\hline
\end{tabular}

Sumber: Pengolahan Data (2017)

Data pada Tabel 10 menunjukkan persentase ketuntasan kelas pada siklus 2 mencapai $87,50 \%$ dan telah memenuhi target penelitian.

\section{Peningkatan Hasil Penelitian dari Siklus 1 ke Siklus 2}

Peningkatan proses pembelajaran sebesar 15,62\%. ditunjukkan pada Gambar 1. 


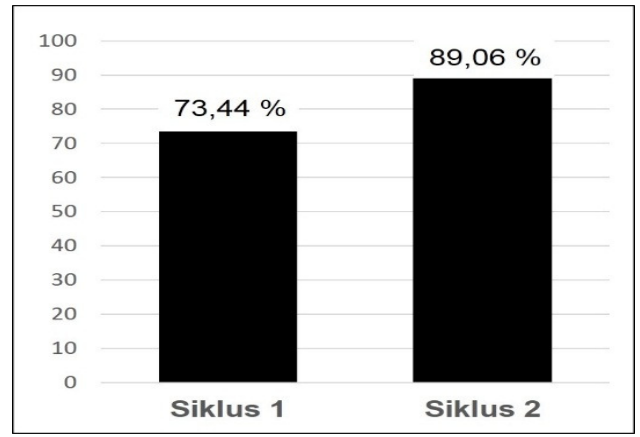

Gambar 1.

Grafik Peningkatan proses Pembelajaran Sumber: Pengolahan Data (2017)

Gambar 2 menunjukkan adanya peningkatan keaktifan siswa dari siklus 1 ke siklus 2 sebesar 15,60\%.

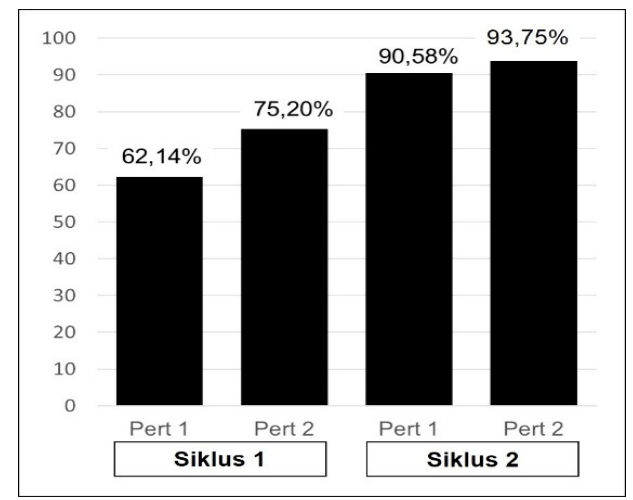

Gambar 2.

Grafik Peningkatan keaktifan siswa Sumber: Pengolahan Data (2017)

Peningkatan Keaktifan per-aspek perilaku yang diamati disajikan pada Gambar 3.

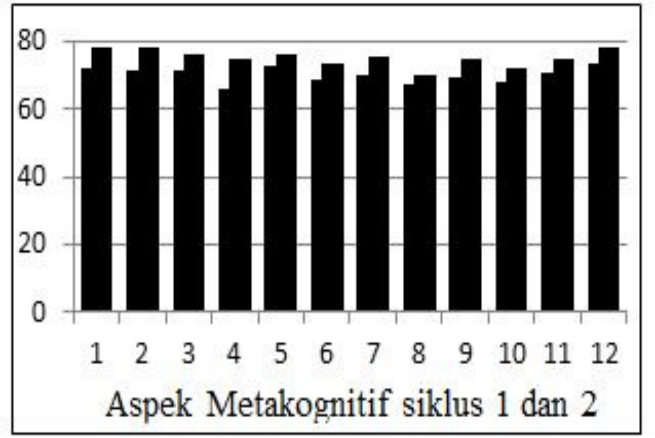

Gambar 3.

Grafik Peningkatan Keaktifan per-aspek perilaku yang diamati

Sumber: Pengolahan Data (2017)

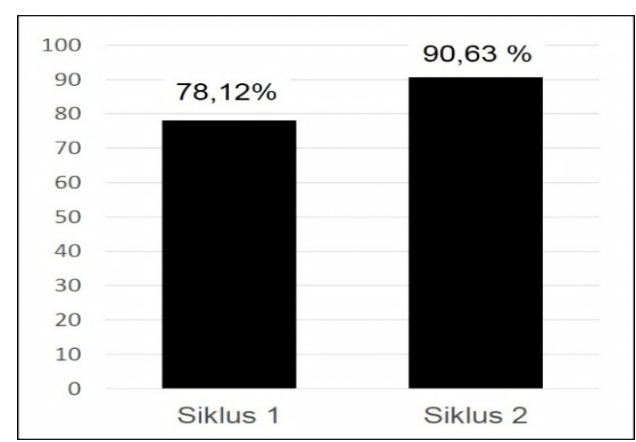

Gambar 4.

Grafik Peningkatan Kemampuan Metakognitif

Sumber: Pengolahan Data (2017)

Peningkatan (hasil angket) kemampuan Metakognitif siswa ditunjukkan Gambar 4 yaitu kemampuan metakognitif dari siklus 1 ke siklus 2 sebesar 12,51\%. Gambar 5 menunjukkan nilai rata-rata yang meningkat sebesar $14,68 \%$ dan peningkatan nilai rata-rata dari kondisi awal sebelum penelitian ke siklus 2 sebesar $38,78 \%$.

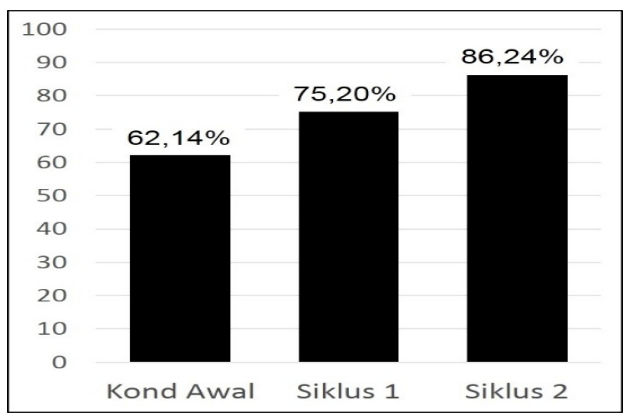

Gambar 5.

Grafik Peningkatan Nilai Rata-rata Sumber: Pengolahan Data (2017)

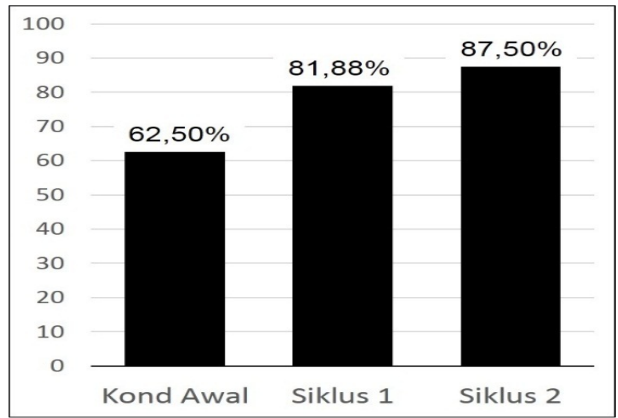

Gambar 6.

Grafik Peningkatan Ketuntasan Belajar Sumber: Pengolahan Data (2017) 
Gambar 6 menunjukkan ketuntasan belajar yang meningkat sebesar 15,62\% dari siklus 1 ke siklus 2 dan meningkat sebesar $25 \%$ dari kondisi sebelum penelitian ke siklus 2 .

\section{Peningkatan Kemampuan Metakognitif}

Kemampuan metakognitif dalam penelitian ini diukur dari hasil angket dan keaktifan siswa dalam melaksanakan kegiatan pembelajaran, yang telah didesain sesuai dengan aspek-aspek kemampuan metakognitif menurut Schraw dan Dennison.

Target keaktifan siswa dalam pembelajaran yang telah ditetapkan adalah sebesar $85 \%$. Keaktifan siswa pada siklus 1 sebesar $76,57 \%$ dari seluruh jumlah siswa, dengan demikian pada siklus 1 dapat dikatakan target belum tercapai. Pada siklus 2 keaktifan siswa mencapai 92,17 \% dari seluruh jumlah siswa, dengan demikian pada siklus 2 target keaktifan belajar siswa telah tercapai. Didukung pula oleh peningkatan persentase keaktifan siswa pada setiap aspek perilaku yang diamati. Rata-rata persentase keaktifan dari seluruh aspek pada siklus 1 sebesar $70,56 \%$, pada siklus 2 meningkat menjadi 75,29\%. Hal ini membuktikan bahwa dengan adanya peningkatan persentase keaktifan belajar siswa dari siklus 1 ke siklus 2 dapat dijadikan indikator adanya peningkatan keaktifan belajar siswa.

Target kemampuan metakognitif siswa yang telah ditetapkan adalah sebesar $85 \%$. Kemampuan metakognitif siswa pada siklus 1 sebesar 78,12\% dari yang diharapkan dengan demikian pada siklus 1 dapat dinyatakan target belum tercapai. Pada siklus 2 kemampuan metakognitif mencapai 90,63\% dari yang diharapkan, dengan demikian pada siklus 2 target kemampuan metakognitif siswa telah tercapai. Hal ini membuktikan bahwa dengan adanya peningkatan persentase kemampuan metakognitif siswa dari siklus 1 ke siklus 2 dapat dijadikan indikator adanya peningkatan kemampuan metakognitif siswa.

\section{Peningkatan Hasil Belajar}

Pengukuran hasil belajar dalam penelitian ini diperoleh dari hasil keterlaksanaan proses pembelajaran yang berpengaruh langsung terhadap hasil belajar, dan tes hasil belajar.

Target untuk keterlaksanaan proses pembelajaran telah ditetapkan sebesar $85 \%$ dari proses pembelajaran yang direncanakan. Pada siklus 1 persentase keterlaksanaan proses pembelajaran mencapai $73,44 \%$ dari yang telah direncanakan, dengan demikian pada siklus 1 dapat dinyatakan target belum tercapai. sedangkan pada siklus 2 meningkat menjadi 89,06\% dari yang direncanakan, sehingga dapat dinyatakan bahwa target keterlaksanaan proses pembelajaran pada siklus 2 telah tercapai. Hal ini membuktikan bahwa dengan meningkatnya persentase keterlaksanaan proses pembelajaran dari siklus $1 \mathrm{ke}$ siklus 2 dapat dijadikan sebagai indikator adanya peningkatan kualitas proses pembelajaran.

Nilai rata-rata sebelum penelitian yaitu 62,14, pada siklus 1 sebesar 75,20 sedangkan pada siklus 2 sebesar 86,24. Dengan demikian terjadi peningkatan nilai rata-rata dari siklus 1 ke siklus 2 sebesar 14,68 \% dan peningkatan nilai rata-rata dari kondisi awal sebelum penelitian ke siklus 2 sebesar 38,78\%.

Jumlah siswa yang telah tuntas belajar sebelum penelitian sebanyak $62,50 \%$, jumlah siswa tuntas belajar pada siklus 1 sebanyak 71,88\% sedangkan pada siklus 2 sebesar $87,50 \%$. Kondisi demikian menunjukkan ketuntasan belajar siswa meningkat sebesar 15,62\% dari siklus 1 ke siklus 2 dan meningkat sebesar $25 \%$ dari kondisi 
sebelum penelitian ke siklus 2. Target ketuntasan hasil belajar siswa yang telah ditetapkan adalah sebesar $85 \%$. Dengan demikian dapat dinyatakan bahwa target ketuntasan hasil belajar pada siklus 2 telah tercapai. Hal ini membuktikan bahwa dengan meningkatnya persentase ketuntasan hasil belajar dari siklus $1 \mathrm{ke}$ siklus 2 dapat dijadikan sebagai indikator adanya peningkatan hasil belajar.

Berdasarkan uraian di atas tampak bahwa dari seluruh indikator kinerja yang ditetapkan dalam Penelitian ini tercapai setelah siklus 2 berakhir, sehingga siklus tidak dilanjutkan. Pembelajaran Sistem Koloid dengan menerapkan model Mersis Pro mampu meningkatkan kemampuan metakognitif dan hasil belajar siswa kelas XI IPA 6 SMA Negeri 1 Pati.

\section{KESIMPULAN DAN SARAN}

\section{Kesimpulan}

Berdasarkan pembahasan dapat disimpulkan: 1) Terjadi peningkatan Keterlaksanaan proses pembelajaran Sistem Koloid dengan menerapkan model Mersis Pro dengan pencapaian $89,06 \%$ (indikator kerja 85\%); 2) Penerapan model Mersis Pro dalam pembelajaran sistem koloid pada siswa kelas XI IPA 6 SMA N 1 Pati dapat meningkatkan keaktifan belajar dengan pencapaian 92,17\% (indikator kerja 85\%) dan kemampuan metakognitif dengan pencapaian sebesar 90,63\% (indikator kerja 85\%); 3) Hasil belajar siswa meningkat dengan pencapaian nilai ratarata sebesar 86,24 dengan ketuntasan belajar secara klasikal sebesar 87,50\% (indikator keberhasilan 85\%).

\section{Saran}

Berdasarkan pelaksanaan dan hasil penelitian yang diperoleh, peneliti memberikan beberapa saran sebagai berikut : (1) Penerapan model Mersis Pro, guru harus lebih banyak memotivasi siswa supaya tidak mudah frustasi dalam menghadapi dan memecahkan masalah yang menantang; (2) Penerapan model Mersis Pro membutuhkan banyak waktu dan biaya, untuk itu diharapkan kepada pihak sekolah untuk mendukung dan memfasilitasi pembelajaran baik dari ketersediaan media maupun sumber belajar; (3) Model pembelajaran Mersis Pro dapat diterapkan pada topik pelajaran kimia yang lain bahkan pada materi pelajaran lain dengan penyesuaian dan modifikasi; (4) Kepada peneliti/guru lain diharapkan untuk mengadakan penelitian lebih lanjut dengan menggunakan instrumen yang lebih lengkap seperti penilaian psikomotor guna mendapatkan temuan yang lebih signifikan.

\section{DAFTAR PUSTAKA}

Andayani. (2012). Problema dan Aksioma: Dalam Metodologi Pembelajaran Bahasa Indonesia. Yogyakarta: CV. Budi Utama.

Coutinho, S. A. (2007). The Relationship Between Goals, Metacognition, and Academic Success. Educate Journal, 7(1). 39-47.

Dryden, G., Vos, J. (2009). Revolusi Cara Belajar (The Learning Rebolution). Bagian II: Sekolah Masa Depan. Terjemahan: Ahmad Baiquni. Bandung: Mizan Media Utama.

Husamah., Setyaningrum, Y. (2013). Desain Pembelajaran Berbasis Pencapaian Kompetensi. Jakarta: Prestasi Pustaka Karya.

Kramarski, B., Mevarech, Z. R. (2003). Enhancing mathematical reasoning in the classroom: The effects of cooperative learning and metacognitive training. American 
Educational Research Journal, 40(1), 281-310.

Nuryana \& Sugiarto. (2012). Hubungan Keterampilan Metakognisi dengan Hasil Belajar Siswa pada Materi Reaksi Reduksi Oksidasi (Redoks) Kelas X-1 SMA Negeri 3 Sidoarjo. Unesa Journal of Chemical Education, 1(1).

Panaoura, A., Philippou, G. (2005). The Measurement of Young Pupils' Metacognitive Ability in Mathematics: The Case of SelfRepresentation and SelfEvaluation, https://books.google. co.id/books?isbn=1135596913, diakses tanggal 7 April 2017.

Rusman. (2010). Model-Model Pembelajaran. Bandung: Rajawali Pers.

Schraw, G., Dennison, R. S. (1994). Assessing metacognitive awareness. Contemporary Educational Psychology, 19, 460475.

Slameto. (2003). Belajar dan Faktor yang Mempengaruhinya. Jakarta: Rineka Cipta.
Sudjana, N. (2005). Penilaian Hasil Proses Belajar Mengajar, Bandung: PT. Remaja Rosdikarya.

Suparno, P. (2008). Filsafat Konstruktivisme Dalam Pendidikan. Yogyakarta: Kanisius.

Suyitno, A. (2005). Petunjuk Praktis Penelitian Tindakan Kelas untuk Penyusunan Skripsi. Semarang: FMIPA UNNES.

Trianto. (2010). Model-Model Pembelajaran Inovatif Berorientasi Konstruktivistik. Jakarta: Prestasi Pustaka Karya.

Wena, M. (2014). Strategi Pembelajaran Inovatif Kontemporer. Jakarta: Bumi Aksara

\section{BIODATA PENULIS}

Idha Nurhayati, lahir, 31 Juli 1968 di Kabupaten Jepara Jawa Tengah. Memperoleh gelar Sarjana Pendidikan Kimia di IKIP Negeri Semarang. Saat ini bekerja sebagai Guru Kimia di SMA Negeri 1 Pati. 